Meta

Journal des traducteurs

Translators' Journal

\title{
MT or CAT: Criteria for the Independant Translator to Select a Computerized System
}

\section{Josette Coughlin}

Volume 35, numéro 2, juin 1990

URI : https://id.erudit.org/iderudit/002415ar

DOI : https://doi.org/10.7202/002415ar

Aller au sommaire du numéro

Éditeur(s)

Les Presses de l'Université de Montréal

ISSN

0026-0452 (imprimé)

1492-1421 (numérique)

Découvrir la revue

Citer cette note

Coughlin, J. (1990). MT or CAT: Criteria for the Independant Translator to Select a Computerized System. Meta, 35(2), 455-457. https://doi.org/10.7202/002415ar d'utilisation que vous pouvez consulter en ligne.

https://apropos.erudit.org/fr/usagers/politique-dutilisation/ 


\section{MT OR CAT: CRITERIA FOR THE INDEPENDENT TRANSLATOR TO SELECT A COMPUTERIZED SYSTEM}

Our purpose here is to guide the independent translator in his choice of a computerized system. But before leading our prospective buyer or lessor through the displays suitable for his purpose, we need to define who he is and what his needs are. It might be easier to start by stating who he is not. In this context he is contrasted with the translator working for a large installation. In other words he is not an in-house translator employed by a large company, institution or organization. This being established, the independent translator remains a multifaceted individual. He can be a literary translator, a technical translator, a parttime translator, a free-lance translator or the owner of a local translation agency or bureau. What characterizes him best, however, whatever his area of specialty and interest may be, is that he is an individual faced constantly with monetary and time constraints. Few professionals have to be more budget conscious and efficient than the independent translator. The reasons for this state of affairs could be the subject of another article but suffice to say here that anyone who has ever worked in translation will agree that keeping operating costs down and using time-saving devices without sacrificing quality of final output are foremost in the mind of the translator who wants to remain in business.

Undoubtedly the reading of professional publications and contacts with other successful colleagues will eventually convince the most recalcitrant independent translator, whether he translates novels or maintenance manuals for heavy equipment, of his need to use computerized tools in order to remain competitive in his field. Once certain of the need to enter the computer age, the intercultural communications specialist faces a first choice: should he opt for a Machine Translation (MT) System which performs the actual translating of the text or should he choose Computer Aids for Translation (CAT) which speed up the tasks of the human translator who continues to operate the transfer of the message from source to target language. Machine Translation (MT) Systems and
Computer Aids for Translation (CAT) have one feature in common, namely to speed up the translating process. They present many differences, the most obvious ones being their cost level for both hardware and software, ease of use, length of training period and areas of application. Until recently MT Systems required the use of main frames or mini computers. Today several companies, among them Weidner Communications Corporation (WCC), LOGOS, ALPS and Linguistic Products offer MT software which can be run on a personal computer such as an IBM XT, an IBM AT or other PCs with comparable capabilities. The lowest investment for such an MT System allowing translation in only one pair of languages such as English-French, French-English would be about $\$ 25,000$ including a letter-quality printer and a modem. The cost of specialized dictionaries, when available, would be additional as well as right of access to electronic data bases and terminology data banks, not to mention input by optical scanner, etc. The initial $\$ 25,000$ investment might be justified if the MT System mentioned above were the answer to most of the needs of the independent translator. Unfortunately that does not seem to be the case at this point in time. Most manufacturers of MT Systems will state that it takes a minimum of three months for installation and training of operators before the system starts to become productive. (Most large installations have required one or two years for their MT Systems to be fully functional!) Assuming that the independent translator has not starved to death during this preparatory period he then discovers that his system is only as good as the size and sophistication of specialized dictionaries available for his system. In other words an MT System functions at its peak level of performance, with the least amount of post-editing or corrections, when translating in a specialized field in which large computerized terminology files are available. Of course terminology files can be created through a "vocabulary update" feature offered by the systems. It should be mentioned, though, that a good terminologist can enter an average of one new term per minute, which, not counting interruptions, represents only sixty new terms per hour, under optimal working conditions. In summary an MT System requires often extensive vocabulary update for each specialized field of translation in which it operates.

Needless to say that MT systems cannot be used to translate literary texts, editorials or advertising material since such systems cannot interpret figurative meaning and are best at translating factual statements and scientific data. By process of elimination we come to the conclusion that only the rare individual who works exclusively in one or two highly specialized technical or scientific fields would be a likely user of MT. Then it follows that the majority of independent translators are left to choose a Computer Aids for Translation or CAT System to speed up their work.

Numerous CAT Systems are available to translators particularly to those using European characters. 
Systems are presently being developed for languages using other alphabets. These will not be discussed here for many are still at an experimental stage. The most inexpensive CAT Systems are no more than multilingual word processing packages allowing the translator easy access to foreign characters and diacritics. More sophisticated CAT Systems offer the translator different features which facilitate his task. In general most CAT Systems offer a split screen mode which either allows the user to view source and target texts simultaneously while working, or permits consultation and update of terminology files while translating is in progress. As first mentioned above, many CAT packages include access to terminology files. In many cases the translator has to prepare his own computerized vocabulary lists but some specialized electronic dictionaries are becoming commercially available. Because software is rarely compatible for several systems, choosing a well-known manufacturer both for hardware and software acquisition has definite advantages even though the initial financial investment may be higher.

Good CAT Systems have many features in common, features which we will review in detail. Before doing so, however, let us briefly talk about hardware. Even though manufacturers may claim that their software requires only $256 \mathrm{~Kb}$ of memory it is wise to acquire hardware with at least $640 \mathrm{~Kb}$ tota capability, including memory extension cards. The amount of memory cited by manufacturers of software to run a particular package usually represents the minimal power needed and does not leave any leeway for additional options such as use of terminology files or the storing of long translation files. Again, because of lack of compatibility between systems, choosing a well-known hardware manufacturer will allow the user to transfer files to clients and colleagues alike without need for conversion which can be time consuming or downright impossible. Desirable software features in CAT Systems can vary slightly depending on individual need but generally all good systems offer a split screen which allows the user to simultaneously use the two halves of the screen for different functions. A horizontal division is mos common. A second important feature is easy access to foreign characters or diacritics. The potential buyer should request to try CAT packages before spending a large sum of money. Several manufacturers make demonstration diskettes available to prospective customers. The future user must also be aware of the fact that some systems offering easy access to foreign characters and diacritics do so at the expense of other characters or signs. For instance an $\dot{e}$, an $\tilde{n}$ or an $a$ might take the place of a mathematical sign such as $\%$ or . For obvious reasons a scientific translator might object to such a loss. In such an instance a better choice would be a CAT System which does not sacrifice any of the mathematical signs but in counterpart permits use of fewer foreign diacritics. Another important feature for most translators is a term counting device which facilitates billing of clients. Still another feature offered by some but not all CAT Systems is storage of terminology files. It is very important to verify that terminology consultation and update are possible while translating is in progress. Should the translator have to leave the word processing mode to look up or update vocabulary or should he have to prepare a handwritten list before electronic input is possible the time-saving element would be partially or completely lost. One more feature offered by some CAT Systems is a terminology search mode during which the document to be translated is scanned for terms not yet entered in the system's dictionaries. The result of the scanning which normally takes place in a matter of seconds or minutes is a "new term" file which can be used to update existing dictionaries prior to translation. An additional benefit of such a scanning device is that it functions as a spelling check since misspelled words will appear as "unknowns" and can be corrected throughout the whole document with a few key strokes. A buffer memory option is particularly useful for legal translators who can store whole paragraphs which are repeated throughout the document, or long names and titles of people which, after initial storage, can be inserted with a couple of key strokes. Customary word processing functions such as additions, deletions, word replacement, paragraph transfer, formatting options are important time-saving devices which are a necessity for all good systems.

The ideal scenario for the independent translator who is ready to make his selection of a CAT System is to try out two or three different models, either thanks to his colleagues' willingness to let him try out their systems, or by requesting a demonstration from the company from which he is considering buying. A demonstration should include a hands-on trial period by the prospective user who should put the system through all the steps he is going to need for his own use. The first step should include electronic and keyboard input of a text. The second step should include vocabulary search and update. The third step should consist of on-line translating. The last step should incorporate formatting, pagination and printing of a camera-ready copy. The future user must insist on the production of a printed or hard copy. Seeing the foreign text on the screen, foreign characters and diacritics included, does not mean, by a long way, that they will print correctly on paper. Foreign characters and diacritics require a special printing wheel and printer. A printer on sale might have a very attractive price tag but will be of no use if it does not print foreign accents. A last word of caution. If at all possible the independent translator should have his CAT System installed during a slow work period, for, invariably, installation and trial periods are frustrating and time consuming. However, in the long run, time and money investments will pay off handsomely both in quality and speed of production of the final text. (The following CAT Systems offer many of the features described above: ALPS, MERCURY, VOLKSWRITER PLUS, etc. For a more 
exhaustive list consult advertisement in professional journals.)

JosetTe COUGHLIN Georgia State University, Atlanta, Georgia, USA 
qu'il devra manifester. Selon la formule célèbre, «le professeur de langue (maternelle ou étrangère) est professeur de vie: il est celui qui doit apprendre à être». Qu'il soit donc préparé à affronter les situations d'enseignement diversifiées. Une telle exigence suppose des dispositions solides de formation continue et d'échanges d'expériences.

- Outils pédagogiques: on a souvent constaté l'inadaptation des matériels disponibles à la diversité des situations locales; ce qui sous-entend le besoin de produire des outils contextualisés. De tels outils ne peuvent être produits que sur place, mais ils doivent pouvoir bénéficier, dans leur élaboration, de la comparaison avec des expériences analogues.

S'agissant des technologies, il conviendrait d'en venir à une conception plus large des outils utilisables, et de ne pas dédaigner le recours à des technologies qui pour être plus anciennes n'en sont pas moins souvent mieux adaptées aux réalités locales.

à l'AUPELF:

Les recommandations suivantes sont adressées

- Création d'un réseau intitulé Sociolinguistique, didactique des langues et gestion de la formation. L'idée, là, est d'analyser la variété des usages de la langue française et d'en tirer des conclusions méthodologiques.

- Mise en place d'une structure d'information et d'échanges d'expériences.

- Mesures concrètes en matière de formation des enseignants (stages transrégionaux ou multinationaux, stages d'enseignants dans d'autres universités).

\section{Sous-thème III}

La réflexion a porté sur Langue francaise et contacts de cultures. Les discussions ont particulièrement mis en lumière les points suivants:

Relation du français et des autres langues

Après avoir constaté

- que la pluralité linguistique est une constante dans la plupart des situations dans lesquelles le français se trouve impliqué, soit à titre de langue étrangère, soit à titre de langue seconde.

a et que cette diversité linguistique, diversement vécue, ne fait pas partout l'objet d'un programme d'aménagement linguistique clairement engagé,

les participants proposent que l'Université joue un rôle important dans ce processus d'aménagement linguistique. Il conviendrait notamment :

a) d'engager des programmes de recherche et d'enseignement allant dans le sens d'une véritable cooperation interculturelle et interlinguistique;

b) de concevoir de nouvelles stratégies tournées vers les champs privilégiés de l'interculturel (études comparatives, traductions, etc.) et d'y adapter la formation des enseignants de français.
Interculturel

On s'est demandé s'il ne convenait pas de commencer la formation-comparaison interculturelle dès le niveau secondaire. Et on a souligné la nécessité de refuser les approximations et l'amateurisme dans le domaine des travaux interculturels. Les bonnes réponses ne peuvent venir que de l'interdisciplinaritié.

On propose donc de favoriser les échanges de professeurs entre espaces francophone et non francophone, d'encourager la création d'équipes multiculturelles pour améliorer la représentation de l'ensemble des pays francophones dans les outils méthodologiques de l'enseignement du français. On propose d'élaborer une typologie des situations d'enseignement prenant en compte les variables culturelles (non systématiquement superposables aux variations sociolinguistiques)

Il conviendrait que l'AUPELF s'interroge dans l'organisation des ses rencontres sur l'articulation entre les industries de la langue, la technologie et la dimension culturelle (formation de la personne, fonction de l'enseignement dans la société). Il serait aussi souhaitable que l'AUPELF suscite, par exemple sous forme de rencontre scientifique de haut niveau, une réflexion approfondie sur les conditions de description des cultures.

Enseignement des littératures et cultures des pays francophones

La réflexion a souligné que l'enseignement de la francophonie se heurte partout à des difficultés nombreuses :

- crédibilité scientifique et légitimation institutionnelle,

- poids symbolique de la France hexagonale,

- statut ambigu des littératures francophones,

- difficulté d'accès aux œuvres et à la documentation, etc.

Les participants recommandent vivement d'intégrer les enseignements concernant les réalités littéraires et culturelles francophones à tous les niveaux des cursus universitaires d'enseignement du français, et particulièrement en France.

D'autre part, ils suggèrent d'encourager la création sur les médias modernes (télévision, vidéo, etc.) et plus généralement d'orchestrer et de valider le travail d'enseignement et de recherche sur d'autres supports que l'écrit.

Les recommandations suivantes, très concrètes, ont été avancées:

- mise à la disposition des centres d'études francophones, et particulièrement dans les pays non francophones, de bibliothèques et vidéothèques minimales;

- élaboration d'appareils critiques et documentaires accompagnant les éditions à grande diffusion des textes francophones;

- fabrication d'usuels (dictionnaires et grammaires) prenant en compte les réalités linguistiques et culturelles de la francophonie ;

- élaboration de banques de données (y compris des répertoires des thèses et des chercheurs et un inventaire des produits médiatiques francophones suscep- 